\title{
Native iron and the associated minerals from the ultramafic masses in the Sanbagawa belt, central Japan
}

\author{
Ryutaro Sakai and Yoshimasu KuRoda \\ Department of Geology, Shinshu University, Matsumoto 390, Japan
}

\begin{abstract}
Native iron has commonly been found in the serpentine vein of the second stage of serpentinization of dunites from the ultramafic masses in the Sarbagawa belt, central Japan. It is nearly pure iron but contains small amounts of $\mathrm{Ni}$ and $\mathrm{Co}$. In the dunites other metallic minerals and sulfides have not yet been found, though magnetite and primary chromite are present. In serpentinized wehrlites from the same masses native iron is almost absent, but in a few of them native cobalt-iron, $\mathrm{CoFe}_{2}$, which is chemically different from wairauite (CoFe), has been found. In the serpentinized wehrlites awaruite and native copper have also been found with sulfides such as pyrrhotite and pentlandite, and oxides such as magnetite and primary chromite. An occurrence of ilvaite and andradite in the serpentinized wehrlites has been noted. The chemical composition and occurrence of these minerals are described. These native metals have been formed during the serpentinization of the dunites and wehrlites.
\end{abstract}

\section{Introduction}

Occurrences of native metals in igneous and metamorphic rocks are important in terms of oxidation-reduction behaviour in the crust and in the mantle. There are many reports on occurrences of various native metals in various rocks, but few on native iron. Native metals found in serpentinites have been well summarized by Ramdohr (1967). Native iron in serpentinites has also been reported from Muskox, Canada, by Chamberlain et al. (1965), from Mina do Abessedo, Portugal, by Clark (1969), from Shaman, Baikal, USSR, by Grudinin and Sekerin (1979), from Kachkanar, Ural, USSR, by Borisenko et al. (1982), and from Vetrenii belt, Baltic schield, USSR, by Skripnichenko et al. (1982). The first discovery of native iron from the serpentinite in Japan has been preliminarily reported by us in the present district (Okamoto et al.,
1981).

Awaruite, $\mathrm{Ni}_{3} \mathrm{Fe}$, has been found from many serpentinites in the world (for example, see Ramdohr (1967) etc.). In Japan, too, it has been already reported from several localities, i.e., in the serpentinites from the Kurosegawa structural belt in Shikoku (Kanehira et al., 1964), in the peridotite from the Mineoka structural belt, Boso peninsula (Kanehira et al. 1975), in the serpentinite from the Sanbagawa belt in central Japan (Onuki et al., 1980) and in the serpentinite from the Kurosegawa structural belt, Kyushu (Okamoto, 1981). We found this mineral in this district, too.

Wairauite, $\mathrm{CoFe}$, is also an interesting and rare native metal mineral. The occurrences have been reported by Challis and Long (1964), Chamberlain et al. (1965), Zimin et al. (1982), and Borisenko et al. (1982) etc. We could not find wairauite in this area, but as will be shown later we

(Manuscript received August 22, 1982) 
found the other kind of cobalt-iron $\left(\mathrm{CoFe}_{2}\right)$.

In this paper we describe the occurrence and chemistry of these native metal minerals and their associated minerals together with a short description of petrography of the ultramafic rocks.

\section{Outline of geology and ultramafic rocks}

The location is in the northern part of the Sanbagawa belt in central Japan (Fig. 1). Median Tectonic Line, dividing the Ryoke belt from the Sanbagawa belt, is situated just at the west of the locality. Geology and petrography of this district have been reported already by lizumi (1968), Makimoto (1978) etc. The metamorphic rocks of the Sanbagawa belt in this district consist mainly of greenschists and black

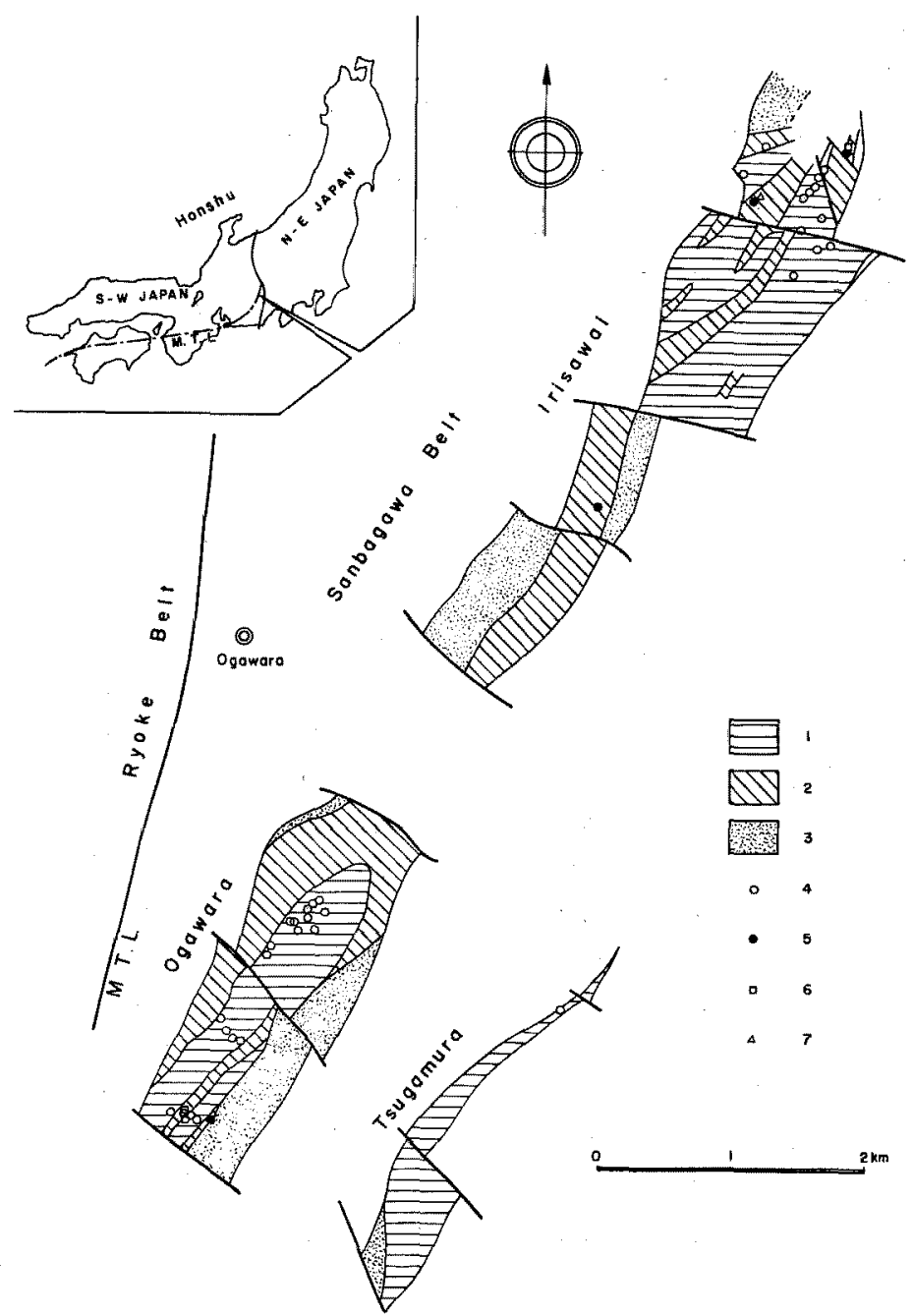

Fig. 1. Locality of native metals in the serpentinites of the Sanbagawa belt, near Ogawara, central Japan.

1, dunite; 2 , wehrlite; 3 , gabbro and hornblendite; 4 , native iron; 5 , awaruite; 6 , cobalt-iron; 7 , copper.

M.T.L., Median Tectonic Line, dividing the Ryoke belt from the Sanbagawa belt. 
schists. The metamorphic grade may be in the lower part of glaucophane-schist facies and a few of the rocks contain albitespots (porphyroblast), which seem to indicate the higher grade of the metamorphism of the Sanbagawa belt.

Three serpentinite masses, Irisawai mass, Ogawara mass, and Tsugamura mass, can be distinguished as seen in Fig. 1. Each mass has elongated to northeastsouthwest direction, which is the general trend of the belt. The Tsugamura mass is composed of completely serpentinized dunite with small amount of gabbro. The other two consists of dunites, wehrlites, pyroxene-gabbro, hornblende-gabbro and hornblendite. The dunites and wehrlites are commonly serpentinized, but the grade of serpentinization differs from place to place. Generally the serpentinization is stronger in the wehrlites than in the dunites, and especially olivine in the wehrlites is easily serpentinized, though clinopyroxene is rather well preserved. The Ogawara mass shows a zonal arrangement of these rocks, i.e., the core consists of the dunites and the periphery is composed of the wehrlites and gabbros. The Irisawai mass shows a parallel arrangement of these rocks.

These masses belong to the Mikabu ultramafic and mafic complex along the Mikabu structural belt in the Sanbagawa belt. According to "Research Group of Peridotite Intrusion" (1967), the peridotites of the Sanbagawa belt, especially those along the Mikabu structural belt, are characterized by the absence of orthopyroxene. In fact, the peridotites in this district do not contain orthopyroxene, that is, they are wehrlites. The wehrlites contain patches or small lenses of aggregates of grossularite, which seem to be derived from plagioclase, but no fresh plagioclase.

The modal composition of these rocks are presented in Table 1 . The dunites consist mainly of olivine, serpentine minerals and ore minerals. Olivine is rather well preserved. Three stages of serpentinization can be often distinguished as stated later.

Table 1. Modal composition of the dunites and wehrlites

\begin{tabular}{|c|c|c|c|c|c|c|c|c|c|c|c|c|c|c|c|}
\hline & $3(0)$ & $6(0)$ & $8(0)$ & $g(D)$ & $10(D)$ & $20(D)$ & $23(D)$ & $25(D)$ & $T(W)$ & $2(W)$ & $7(w)$ & $12(W)$ & $21(W)$ & $24(W)$ & $26(W)$ \\
\hline 1 & 48.9 & 90.8 & 82.5 & & 6.5 & & & 81.7 & 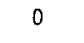 & & 0 & & & 3 & .7 \\
\hline sp(1) & 21.4 & 1.7 & & 0 & 0 & 1 & 7.7 & 0.6 & & & & 7 & 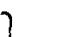 & & ) \\
\hline br & 5.2 & 2.1 & 3.5 & 11.6 & 17.6 & 3.9 & 7.4 & 13.2 & 58.3 & 79.3 & 74.2 & 80.8 & 38.2 & 60.7 & 43.7 \\
\hline$s p(3)$ & 7.9 & 3.5 & 0 & 0 & 0 & 0 & 0 & 0 & & & & & & & \\
\hline $\mathrm{mt}$ & 2.3 & 0.03 & 1.1 & 1.0 & 3.4 & 1.6 & 0.4 & 1.1 & 23.2 & 7.2 & 3.7 & 5.2 & 2.6 & 6.0 & 2.7 \\
\hline$i$. & 0.9 & 0.03 & & 0.6 & & 0.5 & 0.1 & 1.2 & 0 & 0 & 0 & 0 & 0 & 0 & 0 \\
\hline C & 1.7 & 1.8 & 2.0 & 2.9 & 2.5 & 1.7 & 7.0 & 2.2 & 3.5 & 2.6 & 0.5 & 1.1 & 1.7 & 1.8 & 0.4 \\
\hline & 0 & 0 & 0 & 0 & 0 & 0 & 0 & 0 & 2.5 & 0 & 6. & 5.6 & 0.9 & 2.5 & 0 \\
\hline 17 & 7. & 0 & 0 & 0 & 0 & 0 & 0 & 0 & 0 & 7.5 & 1.7 & 0.5 & 7.1 & 11.1 & 19.0 \\
\hline$x(2)$ & 4. & 0 & 0 & 0 & 0 & 0 & 0 & 0 & 12.5 & 2.4 & 13.8 & 6.5 & 17.6 & 17.6 & 33.5 \\
\hline & 10.0 & 99.96 & 100.0 & 00.0 & 100.0 & 00,0 & 100.0 & 100.0 & 100.0 & 100.0 & 100.0 & 100.0 & 100.0 & 100.0 & 100.0 \\
\hline
\end{tabular}

Note: Numbers are the same to those in all figures and tables. (D), dunite; (W), wehrlite. ol, olivine; $\operatorname{sp}(1), \mathrm{sp}(2)$ and $\mathrm{sp}(3)$, serpentine of the first, the second and the third stage serpentinization; br, brucite; $\mathrm{mt}$, magnetite in dunites and magnetite and sulfides in wehrlites; n.i., native iron; gar, grossularite and andradite; $\operatorname{cpx}(1)$ and $\operatorname{cpx}(2)$, the primary and secondary clinopyroxene. 
Ore minerals are native iron, magnetite and primary chromite. In some specimens the amounts of native iron and magnetite have been measured on polished sections. Their amounts and the ratios of native iron to magnetite are variable. Magnetites in the dunites as well as in the wehrlites seem to be not a primary mineral but a secondary mineral during the serpentinization. It is not certain whether magnetite was present as a primary accessory mineral. The amount of chromite is rather constant through the dunites to the wehrlites. The wehrlites should be composed primarily of olivine, clinopyroxene and minor amount of plagioclase, and accessory plate brown hornblende, chromite and sulfides. However, they have been strongly decomposed. Olivine is yet preserved, but few. Plagioclase and hornblende are scarcely preserved. Ore minerals in the wehrlites are more abundant than in the dunites, because of the abundant presence of sulfides such as pyrrhotite and pentlandite. The different stages of serpentinization can not be distinguished in the wehrlites as recognized in the dunites.

Chemical compositions of olivine, primary clinopyroxene and chromite are given in Tables 2 and 3 . Forsterite content of olivine ranges from 87 to 92 mole $\%$ both in the dunites and wehrlites. Its $\mathrm{NiO}$

Table 2. Chemical composition of the primary and secondary silicate minerals

\begin{tabular}{|c|c|c|c|c|c|c|c|c|c|c|c|c|c|c|c|}
\hline & \multicolumn{10}{|c|}{ olivine } & \multicolumn{5}{|c|}{ primary pyroxene } \\
\hline & $5(D)$ & $8(D)$ & $9(D)$ & $10(0)$ & $11(0)$ & $12(W)$ & $21(D)$ & $22(0)$ & $23(0)$ & $26(W)$ & $2(w)$ & $12(W)$ & $13(w)$ & $24(W)$ & $26(\mathrm{H})$ \\
\hline $\mathrm{SiO}_{2}$ & 40.49 & 39.26 & 40.56 & 40.45 & 40.94 & 40.14 & 39.18 & 39.14 & 40.44 & 41.04 & 52.01 & 52.24 & 52.26 & 54.74 & 52.18 \\
\hline $\mathrm{TiO}_{2}^{2}$ & 0 & 0 & 0 & 0 & 0 & 0 & 0 & 0 & 0 & 0 & 0.65 & 0.36 & n.d. & 0.03 & 0.11 \\
\hline $\mathrm{Al}_{2} \mathrm{O}_{3}$ & 0.03 & 0 & 0.04 & 0.03 & 0.01 & 0.07 & 0.04 & 0.04 & 0 & 0.07 & 3.30 & 3.52 & 3.58 & 3.68 & 3.28 \\
\hline $\mathrm{Fe}_{2} \mathrm{O}_{3}$ & - & - & - & - & - & - & - & - & - & - & - & - & - & - & - \\
\hline $\mathrm{FeO}$ & 8.15 & 11.93 & 11.33 & 8.07 & 9.35 & 12.12 & 10.76 & 12.30 & 9.50 & 11.71 & 3.26 & 3.26 & 3.68 & 3.54 & 2.75 \\
\hline Mno & 0.16 & 0.21 & 0.23 & 0.17 & 0.26 & 0.30 & 0.19 & 0.26 & 0.22 & 0.25 & 0 & 0 & 0.07 & 0.12 & 0.07 \\
\hline MgO & 49.42 & 46.78 & 48.08 & 49.55 & 49.05 & 47.47 & 48.39 & 47.93 & 48.93 & 48.16 & 16.70 & 16.11 & 15.90 & 16.05 & 15.44 \\
\hline $\mathrm{CaO}$ & 0.18 & 0.28 & 0.09 & 0.28 & 0.26 & 0.07 & 0.03 & 0.06 & 0.17 & 0.03 & 21.85 & 23.25 & 23.54 & 20.95 & 24.08 \\
\hline $\mathrm{Na}_{2} \mathrm{O}$ & 0 & 0 & 0 & 0 & 0 & 0 & 0 & 0 & 0 & 0 & 0.20 & 0.12 & 0.37 & 0.32 & 0.34 \\
\hline NiO & 0.41 & 0.34 & 0.41 & 0.43 & 0.34 & 0.44 & 0.28 & 0.32 & 0.41 & 0.35 & 0,16 & 0.12 & n.d. & 0.14 & 0.19 \\
\hline $\mathrm{Cr}_{2} \mathrm{O}_{3}$ & n.d. & n.d. & n.d. & n.d. & n.d. & n.d. & n.d. & n.d. & n.d. & n.d. & n.d. & 1.20 & n.d. & 1.16 & 1.26 \\
\hline Total & 98.84 & 98.80 & 100.74 & 98.98 & 100.21 & 100.55 & 98.87 & 100.05 & 99.61 & 101.61 & 98.13 & 100.18 & 99.40 & 100.73 & 99.70 \\
\hline
\end{tabular}

\begin{tabular}{|c|c|c|c|c|c|c|c|c|c|c|c|c|c|c|}
\hline \multicolumn{4}{|c|}{ secondary pyroxene } & \multicolumn{8}{|c|}{ serpentine } & \multicolumn{2}{|c|}{ andradite } & \multirow{2}{*}{$\frac{i l v a .}{7(W)}$} \\
\hline $1(w)$ & $7(w)$ & $13(W)$ & $24(W)$ & $1(w)$ & $2(W)$ & $4(02)$ & $4(03)$ & $5(D 2)$ & $7(\mathrm{~W})$ & $23(02)$ & $26(W)$ & $7(w)$ & $13(W)$ & \\
\hline 51.76 & 53.56 & 51.79 & 55.36 & 43.11 & 43.11 & 40.35 & 41.05 & 44.04 & 42.77 & 43.67 & 41.92 & 33.28 & 35.83 & 31.00 \\
\hline- & - & - & - & 0.37 & 0.56 & 0.86 & 1.23 & 0 & 1.54 & 0.04 & 0.71 & 0.13 & 0 & n.d. \\
\hline 0.60 & 0.44 & 3.67 & 0.26 & 4.94 & 1.60 & 2.99 & 3.21 & 2.89 & 3.41 & 2.32 & 3.52 & 2.15 & 2.24 & 0.03 \\
\hline- & - & - & - & - & - & - & - & - & - & $\omega$ & - & 29.73 & 27.29 & $19.12 *$ \\
\hline 3.04 & 2.43 & 4.20 & 1.99 & 0.08 & 0.04 & 0.08 & 0.09 & 0.05 & 0.12 & 0.05 & 0.11 & - & - & $27.41 *$ \\
\hline 0.21 & 0.31 & 0.07 & 0.15 & n.d. & n.d. & n.d. & n.d. & n.d. & n.d. & n.d. & n.d. & 0.07 & 0.06 & 2.52 \\
\hline 21.73 & 19.83 & 21.41 & 20.82 & 39.25 & 43.54 & 39.62 & 39.57 & 42.38 & 40.50 & 43.08 & 40.70 & 0.53 & 0.65 & 1.99 \\
\hline 22.71 & 22.15 & 17.64 & 27.63 & 0.02 & 0.21 & 0.14 & 0.16 & 0.13 & 0.06 & 0.08 & 0.16 & 33.02 & 32.50 & 13.98 \\
\hline 0.06 & 0 & 0.36 & n.d. & $n . d$. & n.d. & n.d. & n.d. & n.d. & 0.04 & n.d. & 0 & n.d. & n.d. & n.d. \\
\hline 0.15 & n.d. & $n . d$. & 0.26 & 0.15 & 0.05 & n.d. & n.d. & 0.06 & 0.10 & 0.06 & 0.04 & 0.07 & 0 & 0.08 \\
\hline n.d. & n.d. & n.d. & n.d. & n.d. & n.d. & n.d. & n.d. & n.d. & n.d. & $n, d$. & n.d. & n.d, & n.d. & n.d. \\
\hline 100.26 & 98.72 & 99.14 & 100.47 & 87.92 & 89.11 & 84.04 & 85.31 & 89.55 & 88.54 & 89.30 & 87.16 & 98.98 & 98.57 & 96.16 \\
\hline
\end{tabular}

D2, serpentine from the second stage vein in dunite; D3, serpentine from the third stage vein in dunite.

*, calculated value from the EPMA analysis 
Table 3. Chemical composition of primary chromite and magnetite from the dunites and wehrlites

\begin{tabular}{|c|c|c|c|c|c|c|c|c|c|c|c|c|c|c|c|}
\hline & $1(w)$ & $5(0)$ & $7(W)$ & $9(D)$ & $11\langle 0\rangle$ & $12(w)$ & $22(D)$ & $23\langle 0\rangle$ & $24(W)$ & $26(W)$ & $T(W)$ & $5(0)$ & $7(\mathrm{~N})$ & $23(0)$ & $26(W)$ \\
\hline $\mathrm{TiO}_{2}$ & 0.84 & 0.68 & 0.44 & 0.44 & 0.15 & 0.61 & 0.26 & 0.84 & 0.86 & 0.36 & 0.04 & 0 & 0.06 & 0.04 & 0.74 \\
\hline $\mathrm{Al}_{2} \mathrm{O}_{3}$ & 23.31 & 22.26 & 19.60 & 18.18 & 23.76 & 31.22 & 27.14 & 20.47 & 21.50 & 30.25 & 0 & 0.03 & 0.05 & 0 & 0.03 \\
\hline $\mathrm{Fe}_{2} \mathrm{O}_{3}$ * & 13.48 & 7.48 & 16.50 & 19.56 & 11.17 & 5.05 & 15.61 & 8.86 & 16.43 & 5.65 & 68.48 & 68.42 & 68.24 & 68.17 & 65.77 \\
\hline $\mathrm{FeO} *$ & 23.64 & 15.07 & 25.17 & 21.60 & 17.13 & 23.98 & 21.16 & 18.42 & 22.63 & 19.36 & 30.19 & 29.91 & 30.00 & 30.35 & 29.76 \\
\hline $\mathrm{MnO}$ & 0.24 & 0.18 & 0.27 & 0.10 & 0.25 & 0.34 & 0.18 & 0.18 & 0.34 & 0.19 & 0.04 & 0.06 & 0.09 & 0.08 & 0.10 \\
\hline Mgo & 7.41 & 12.34 & 5.87 & 7.63 & 11.56 & 8.02 & 9.59 & 10.29 & 7.66 & 11.05 & 0.02 & 0.10 & 0.04 & 0.15 & 0.06 \\
\hline $\mathrm{Cr}_{2} \mathrm{O}_{3}$ & 31.76 & 39.99 & 31.37 & 30.51 & 35.29 & 31.20 & 27.47 & 39.78 & 30.49 & 3294 & 0.25 & 0.16 & 0.27 & 0.02 & 0.63 \\
\hline Total & 100.68 & 98.00 & 99.22 & 98.02 & 99,31 & 100.42 & 101.41 & 98.84 & 9991 & 99.80 & 99.02 & 98.68 & 98.75 & 98.81 & 96.49 \\
\hline $\mathrm{MgAl}_{2} \mathrm{O}_{4}$ & 34.42 & 42.34 & 29.37 & 36.69 & 44.36 & 37.53 & 44.68 & 39.23 & 37.60 & 50.40 & 0 & - & 0.10 & - & 0.01 \\
\hline $\mathrm{FeCr}_{2} \mathrm{O}_{4}$ & 38.09 & 34.07 & 41.62 & 39.78 & 33.99 & 38.74 & 34.00 & 40.46 & 39.72 & 39.88 & 0.31 & - & 0.30 & - & 0.97 \\
\hline $\mathrm{MgCr}_{2} \mathrm{O}_{4}$ & - & 16.96 & - & 1.49 & 10.21 & - & - & 10.66 & - & - & 0.10 & - & 0.10 & - & 0.04 \\
\hline $\mathrm{FeFe}_{2} \mathrm{O}_{4}$ & 13.85 & 6.63 & 19.61 & 22.03 & 11.43 & 2.97 & 15.95 & 9.64 & 18.49 & 5.57 & 99.60 & - & 9949 & - & 98.99 \\
\hline $\mathrm{FeAl}{ }_{2} \mathrm{O}_{4}$ & 13.75 & - & 9.40 & - & - & 20.75 & 5.37 & - & 4.18 & 4.15 & - & - & - & - & - \\
\hline
\end{tabular}

*, calculated values from EPMA analyses.

content is 0.3 to $0.4 \%$. Primary clinopyroxene is diopsidic augite and $\mathrm{Cr}_{2} \mathrm{O}_{3}$ content is about $1.2 \%$. The compositions of the chromites are somewhat variable. Generally they are rather rich in $\mathrm{Al}, \mathrm{Fe}^{2+}$ and $\mathrm{Fe}^{3+}$, and poor in $\mathrm{Cr}$ compared to chromite compositions usually found in dunites and peridotites. Magnesiochromite molecule in the calculated chemical formula appears only in the chromites from the dunites, but there is no big difference between those in the dunites and those in the wehrlites on a $\mathrm{Fe}^{3+-} \mathrm{Cr}-\mathrm{Al}$ diagram (Fig. 2). According to the spinel-olivine geothermometer of Fabries (1979), the equilibrium temperature of chromite and olivine can be estimated to be about $800^{\circ} \mathrm{C}$ for the dunites and $600-700^{\circ} \mathrm{C}$ for the wehrlites. The

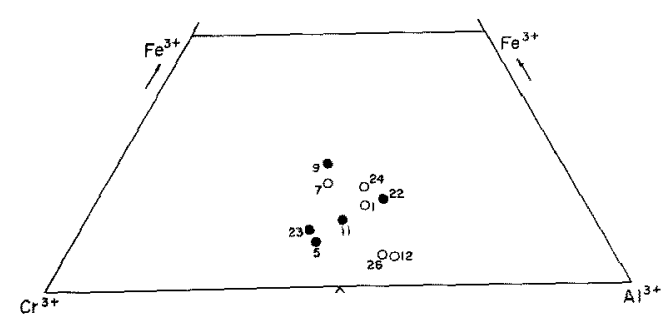

Fig. 2. Fe-Cr-Al diagram for chrcnites. open circle, in wehrlites; solid circle, in dunites (Table 3 ). values are too low to represent the primary crystallization temperature of peridotites. This may depend on the change of composition of chromite during the serpentinization.

Chemical compositions of serpentines and secondary fibrous clinopyroxene are presented in Table 2 . In the serpentines there are antigorite, crysotile and lizardite, of which occurrences will be described later. There is no big difference among the compositions of serpentines. During the serpentinization the aggregate of fibrous clinopyroxene has been formed as a pseudomorph after olivine or as an independent aggregate abundantly in the wehrlites and a few in the dunites. The secondary clinopyroxene is depleted in $\mathrm{Al}$ and $\mathrm{Cr}$, and is enriched in $\mathrm{Mg}$ relative to the primary clinopyroxene (see Table 2). The composition of the secondary magnetite is also presented in Table 3 . They are almost pure magnetite.

As shown later, native iron has been formed at the second stage of serpentinization, where a partial magnetitization of chromite has also taken place. Serpentinization of wehrlites is also accompanied by the formation of awaruite, native cobalt- 
iron, native copper, ilvaite and andradite. The second stage serpentinization of the dunites and the serpentinization of the wehrlites are characteristically accompanied by the formation of brucite.

\section{Native metals and related minerals}

Native iron In the dunites three stages of serpentinization can be distinguished as shown in Fig. 3-1. The serpentinization of
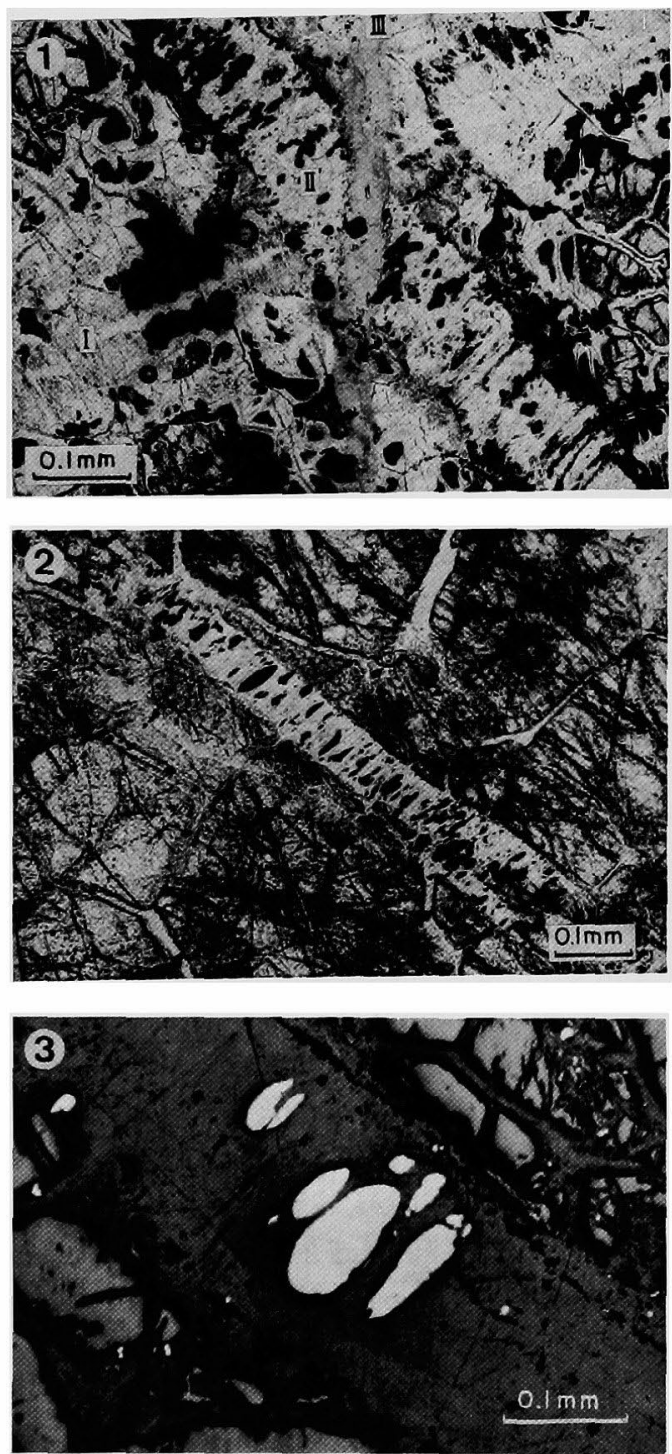

the first stage appears in the whole rock and the product consists of the matrix of the rocks, though it looks like a vein in some parts. The main mineral of this serpentinization is lizardite and is associated with many small grains of magnetite. The serpentinization of the second stage appears as veins, which cut the first stage serpentine mineral and contain native iron (Fig. 3-1, $-2)$. The main mineral of these veins is
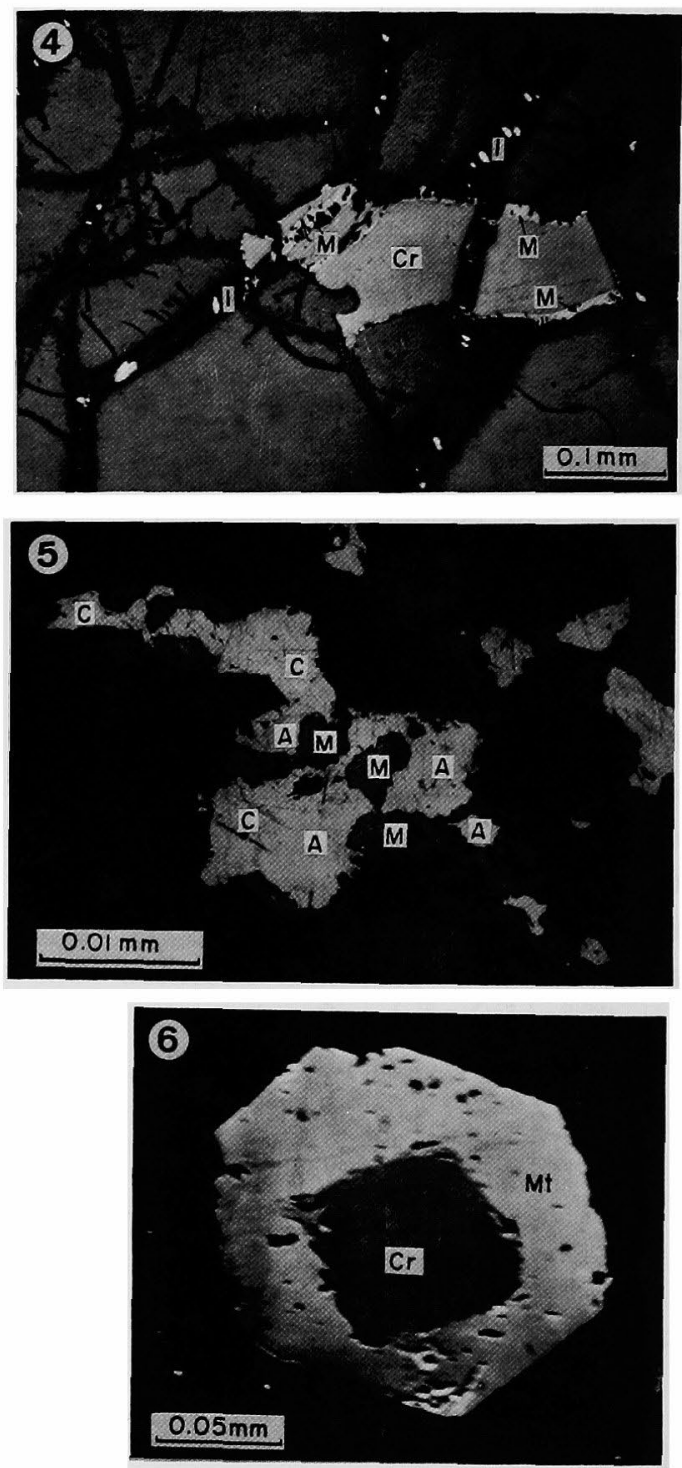
crysotile, and brucite is characteristically recognized, which has been also reported in other localities of native iron (Chamberlain et al. 1965, Grudinin and Sekerin 1979, etc.). The appearance of brucite during the formation of native iron would be inevitable as Grudinin and Sekerin (1979) discussed. The veins of the second stage serpentinization are cut by the third stage veins, consisting mainly of lizardite. The third stage veins do not contain native iron and magnetite. The grade of development of these three stages of serpentinization is different from place to place (Table 1). Especially the third stage is developed locally.

Native iron often shows an ovoidal form and its longitudinal axis up to $150 \mu \mathrm{m}$ is always perpendicular to the wall of the veins as seen in Fig. 3-2, -3. Irregular shaped ones are surrounded by magnetite. The amounts of native iron and magnetite in the veins are different from place to place. When chromite is cut by the second stage serpentine veins, secondary magnetite is produced as seen in Fig. 3-4. Sometimes chromite is completely surrounded by magnetite (Fig. 3-6). In the wehrlites native iron has not yet found except in one case as stated later.

Chemical compositions of the native irons are given in Table 4. They are nearly pure iron as those of the other localities (Chamberlain et al. 1965, Borisenko et al. 1982). Ni content and Co content are small (less than $2.0 \%$ for $\mathrm{Ni}$ and usually less than $1.0 \%$ for $\mathrm{Co}$ ). The contents of $\mathrm{Ni}$ and $\mathrm{Co}$ are slightly higher in the central part of grains than in the periphery. $\mathrm{Cr}$ is not contained. In Muskox, native iron is associated with awaruite, wairauite and native copper, and in Mina do Abbesedo it is accompanied by chromian mackinawite. In Kachkanar it is associated with nickeliron $(\mathrm{NiFe})$, wairauite $(\mathrm{CoFe})$ and awaruite $\left(\mathrm{Ni}_{3} \mathrm{Fe}\right)$. In our study, however, native iron is not associated with an metallic mineral, except only one case in the wehrlite as stated later. The occurrence of native iron suggests that it had been formed during the serpentinization as in the other localities such as Muskox, Mina do Abessedo, Kachkanar, Shaman etc.

Awaruite This mineral has been found only in the wehrlites and has not yet been found in the dunites. In the wehrlites different stages of serpentinization like in the dunites are not recognized, but awaruite and other

Fig. 3. Occurrences of serpentine minerals, native metals and oxides.

1. Three stages of serpentinization in the dunite (Sample No. 3D) (polarizing microscope, one nicol).

I, serpentine mineral of the first stage; II, serpentine vein of the second stage, cutting serpentine mineral of the first stage and being cut by serpentine vein of the third stage; III, serpentine vein of the third stage.

2. The second stage serpentine vein including native iron and magnetite (Sample No. 9D) (polarizing microscope, one nicol).

The ovoid and lenticular opaque minerals perpendicular to the wall of vein are native irons, and irregular ones are magnetite.

3. Native iron (Sample No. 9D) (reflecting microscope).

The bright ovoids are native irons.

4. Magetite (M), surrounding and cutting chromite (Cr), being closely accompanied by serpentine veins of the second stage, which contain native iron (I) (Sample No. 9D) (reflecting microscope).

5. The relationship of awaruite (A), native copper (C) and magnetite (M) (Sample No. 7W) (reflecting microscope).

6. Chromite (Cr), surrounded by magnetite (Mt) (Sample No. 1W) (backscattered electron image). 
Table 4. Chemical composition of native metals and sulfides

\begin{tabular}{|c|c|c|c|c|c|c|c|c|c|}
\hline \multirow[b]{2}{*}{$w t \%$} & \multicolumn{6}{|c|}{ iron } & \multicolumn{3}{|c|}{ awaruite } \\
\hline & $3(D)$ & $6(D)$ & $9(D)$ & $23(D)$ & $25(0)$ & $26(W)$ & $1(W)$ & $7(W)$ & $27(W)$ \\
\hline $\mathrm{Fe}$ & $\begin{array}{c}99.04 \\
(98.50-99.70)\end{array}$ & 96.20 & $\begin{array}{c}98.59 \\
(97.90-99.97)\end{array}$ & 97.00 & 97.30 & 94.12 & $\begin{array}{c}30.50 \\
(29.00-32.00)\end{array}$ & $\begin{array}{c}30.80 \\
(28.60-32.50)\end{array}$ & $\begin{array}{c}25.13 \\
(24.00-27.00)\end{array}$ \\
\hline $\mathrm{Ni}$ & $\begin{array}{c}0.26 \\
(0.20-0.30)\end{array}$ & 1.60 & $\begin{array}{c}0.75 \\
(0.20-1.10)\end{array}$ & 2.00 & 1.60 & 2.03 & $\begin{array}{c}66.65 \\
(66.00-67.30)\end{array}$ & $\begin{array}{c}65.80 \\
(64.90-67.70)\end{array}$ & $\begin{array}{c}70.05 \\
(68.50-71.60)\end{array}$ \\
\hline Co & $\begin{array}{c}0.26 \\
(0.20-0.30)\end{array}$ & 1.80 & $\begin{array}{c}0.34 \\
(0.15-0.50)\end{array}$ & 0.10 & 0.70 & 2.78 & $\begin{array}{c}2.85 \\
(2.00-3.70)\end{array}$ & $\begin{array}{c}2.08 \\
(2.00-2.30)\end{array}$ & $\begin{array}{c}1.08 \\
(0.80-1.50)\end{array}$ \\
\hline $\mathrm{Cu}$ & 0 & 0 & 0 & 0 & 0 & 0 & 0 & $\begin{array}{c}0.24 \\
(0-0.50)\end{array}$ & $(1.00-5.00)$ \\
\hline$s$ & 0 & 0 & 0 & 0 & 0 & 0 & 0 & 0 & 0 \\
\hline Total & 99.54 & 99.60 & 99.68 & 99.10 & 99.60 & 98.93 & 100.00 & 98.92 & 99.51 \\
\hline \multicolumn{10}{|l|}{ at\% } \\
\hline $\mathrm{Fe}$ & 99.52 & 96.74 & 98.93 & 97.97 & 97.81 & 95.36 & 37.58 & 32.20 & 26.29 \\
\hline $\mathrm{Ni}$ & 0.25 & 1.52 & 0.73 & 1.92 & 1.52 & 1.98 & 65.64 & 65.52 & 69.68 \\
\hline Co & 0.23 & 1.74 & 0.34 & 0.09 & 0.67 & 2.66 & 2.78 & 2.05 & 1.05 \\
\hline $\mathrm{Cu}$ & 0 & 0 & 0 & 0 & 0 & 0 & 0 & 0.23 & 2.92 \\
\hline$S$ & 0 & 0 & 0 & 0 & 0 & 0 & 0 & 0 & 0 \\
\hline
\end{tabular}

\begin{tabular}{|cc|cc|cc|cc}
\hline \multicolumn{2}{|c|}{ cobalt-iron } & \multicolumn{2}{|c|}{ copper } & \multicolumn{2}{c|}{ pyrrhotite } & \multicolumn{2}{c}{ pentiandite } \\
\hline $1(W)$ & $26(W)$ & $7(W)$ & $27(W)$ & $1(W)$ & $7(W)$ & $1(W)$ & $7(W)$ \\
\hline 62.87 & 66.57 & 0.30 & 0.46 & 65.23 & 62.37 & 44.24 & 45.31 \\
$(62.70-63.10)$ & & $(0-0.60)$ & $(0.30-0.80)$ & & & & \\
0.36 & 1.04 & 1.77 & 3.34 & 0 & 0 & 20.00 & 20.17 \\
$(0-0.60)$ & & $(1.50-2.00)$ & $(3.00-3.50)$ & & & & \\
35.77 & 33.46 & 0 & 0 & 0 & 0 & 1.55 & 0 \\
$(35.70-35.90)$ & & & & & & & \\
0 & 0 & 98.00 & 94.24 & 0 & 0 & 0 & 0.50 \\
& & $(97.10-99.00)$ & $(93.70-95.30)$ & & & & \\
0.30 & 0 & 0.27 & 0.86 & 36.86 & 36.63 & 32.86 & 32.31 \\
$(0-0.50)$ & & $(0-0.80)$ & $(0.30-1.20)$ & & & & \\
99.30 & 101.07 & 100.34 & 98.90 & 100.09 & 99.00 & 98.65 & 98.29 \\
\hline & & & & & & & \\
64.34 & 67.04 & 0.32 & 0.51 & 49.56 & 49.38 & 36.23 & 37.32 \\
0.34 & 1.01 & 1.89 & 3.62 & 0 & 0 & 15.60 & 15.83 \\
34.80 & 31.95 & 0 & 0 & 0 & 0 & 1.19 & 0 \\
0 & 0 & 97.29 & 94.16 & 0 & 0 & 0 & 0.37 \\
0.51 & 0 & 0.50 & 1.71 & 50.44 & 50.62 & 46.96 & 46.48
\end{tabular}

native metals are always found in the serpentine minerals.

The analytical results are given in Table 4. $\mathrm{Ni} / \mathrm{Fe}$ ratios are rather variable (from 1.9 to 2.7) from place to place. Even in the same specimen the composition is variable from grain to grain, but in a single grain no compositional variation is found. Some of the awaruite grains contain fairly large amount of $\mathrm{Cu}$, but it might be derived from very small grains of native copper included in the awaruite. As seen in Fig. 3-5, it is often associated closely with native copper and magnetite.

Native cobalt-iron This mineral has been found in two specimens of wehrlite (Nos. 1 and 26). Challis and Long (1964) reported wairauite, $\mathrm{CoFe}$, associated with awaruite, 

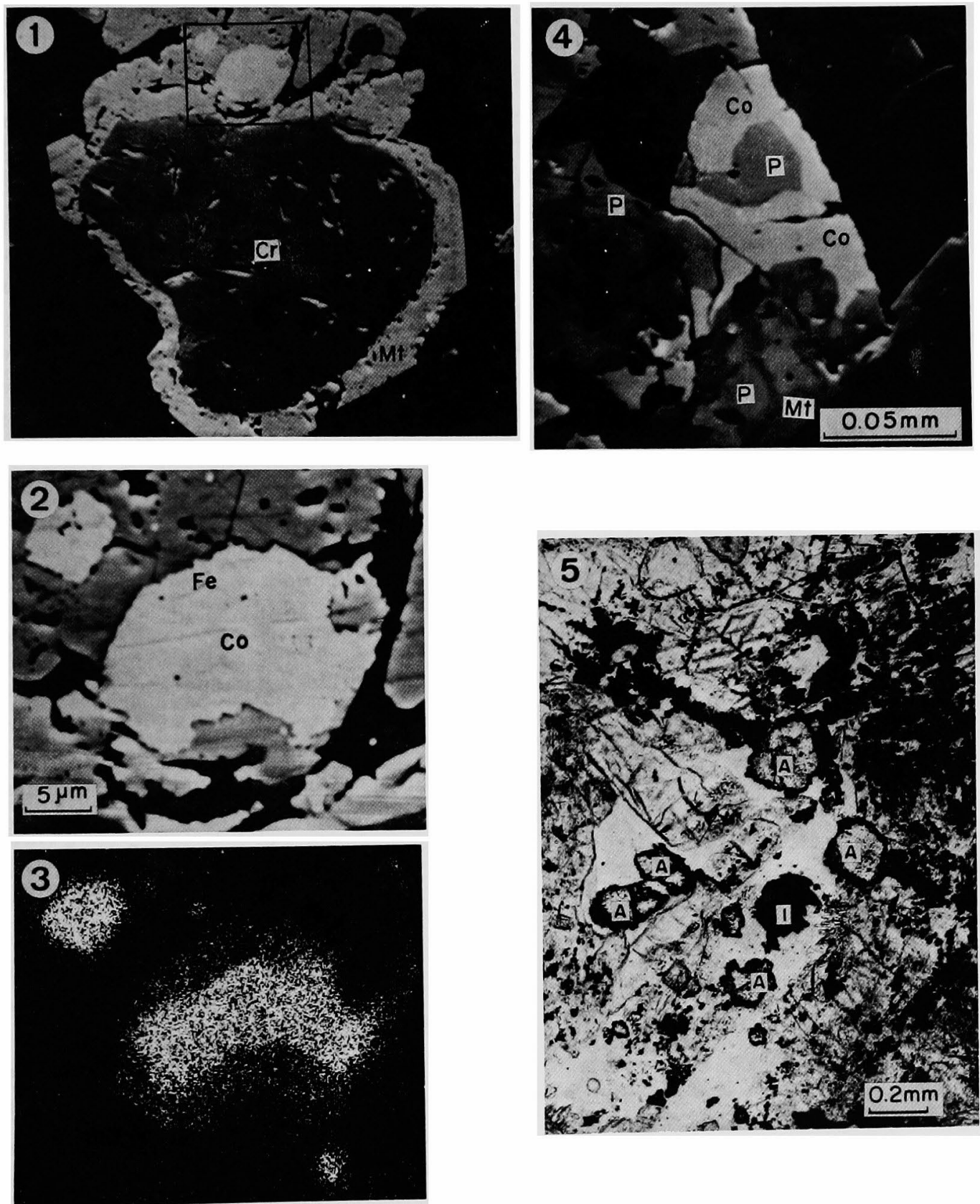

Fig. 4. Occurrences of native metals and other minerals.

1. Relationship of native metals (white parts in quadrnagle), chromite $(\mathrm{Cr})$ and magnetite (Mt) (Sample No. 26W) (backscattered electron image).

2. Quardrangle in 1, enlarged. Cobalt-iron (Co) surrounded by native iron (Fe) (backscattered electron image).

3. CoKo: radiation image of the same part of 2 . $(\mathrm{Mt})$ and pyrrhotite (P) (Sample No. 1W)

(backscattered electron image).

5. Occurrence of ilvaite (I) and andradite (A) (Sample No. 7W) (polarizing microcope, one nicol). 
magnetite and chromite from Red Hills serpentinite in New Zealand, and Chamberlain et al. (1965) also found the same mineral as an isolated grain from the wehrlite in Muskox. Borisenko et al. (1982) reported the same mineral with native iron in Kachkanar. Zimin et al. (1982) reported the mineral with native Os-Ir minerals from the serpentinites. In one specimens of wehrlite (No. 26) the mineral occurs as small grains surrounded by magnetite, which also surrounds chromite (Fig. 4-1, -2, -3). The marginal part of the cobalt-iron is native iron (Fig. 4-2, -3), which is the only one occurrence of native iron in the wehrlites. The chemical analyses of the minerals are given in Table 4. Native iron surrounding cobalt-iron is rich in Co $(2.78 \%)$. In the other specimen (No. 1) it is closely associated with pyrrhotite and magnetite (Fig. 4-4). Analytical result of the mineral is also presented in Table 4. From the analyses the cobalt-iron is $\mathrm{CoFe}_{2}$, not $\mathrm{CoFe}$, and it seems to be different from wairauite. The compositions of native irons, cobalt-irons and awaruites are plotted on $\mathrm{Fe}-\mathrm{Co}-\mathrm{Ni}$ diagram (Fig. 5).

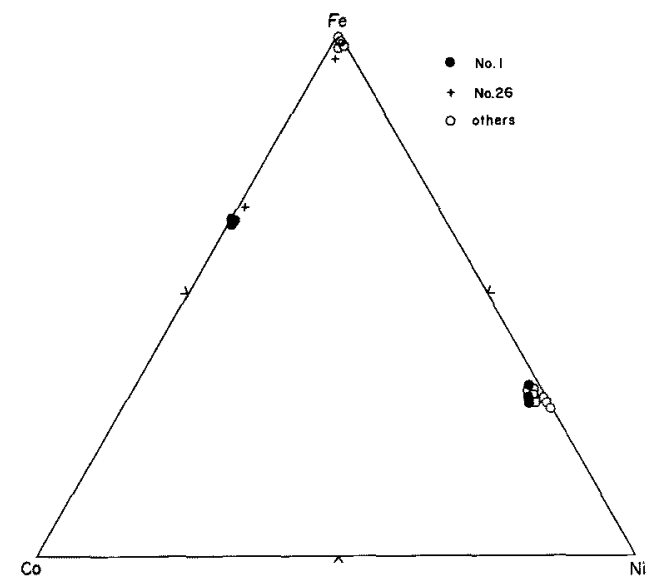

Fig. 5. Fe-Co-Ni diagram for native metals (native iron, cobalt-iron and awaruite) (from Table 4),
Native copper This is also found in the wehrlites and is often associated with awaruite as shown in Fig. 3-5. The chemical composition is homogeneous in individual grains. The analyses presented in Table 4 show a small content of $\mathrm{Ni}$ and no Co. Presence of small amount of S may be derived from small grains of sulfides. Pyrrhotite and pentlandite These minerals are also found in the wehrlites. Chemical analyses are presented in Table 4 , and some relationship with the other minerals are already described. The composition of pyrrhotite is close to the stoichiometric FeS (troilite). This may show a low temperature of formation, because coexisting of awaruite, Fe-rich pentlandite and pyrrhotite close to troilite is known as a low temperature assemblage by Misra and Fleet (1973).

Ilvaite and andradite In saussuritic parts of the wehrlites andradite and ilvaite are found (Fig. 4-5). Their chemical compositions are listed in Table 2. Andradite is nearly pure andradite, and ilvaite contains some amount of $\mathrm{Mn}(\mathrm{MnO} 2.52 \%)$. The saussuritic parts have been formed contemporaneously with the serpentinization and may be similar to a rodingite in composition.

\section{Discussion}

Native iron is found in the dunites, and awaruite, native cobalt-iron and native copper are found in the wehrlites, which is an interesting observation. In all cases the native metals are intimately related to the serpentinization. This is especially distinct for the native iron, which is found only in the second stage of serpentinization in the dunites.

It has been well known that iron is released from olivine during the serpentiniza- 
tion and it makes magnetite. At the moment, if the reduction is conducted, native iron would be formed. Chamberlain et al. (1965) pointed out that hydrogen gas evolves in the process of serpentinization as the following reaction,$$
6 \mathrm{Mg}_{1.5} \mathrm{Fe}_{0.5} \mathrm{SiO}_{4}+7 \mathrm{H}_{2} \mathrm{O}=3 \mathrm{Mg}_{3} \mathrm{Si}_{2} \mathrm{O}_{5}(\mathrm{OH})_{4}+
$$$$
\text { olivine }
$$$$
\text { serpentine }
$$$$
\mathrm{Fe}_{3} \mathrm{O}_{4}+\mathrm{H}_{2} \text {. }
$$$$
\text { magnetite }
$$

If it is so, the hydrogen gas would reduce magnetite to native iron and sulfides such as pentlandite and chalcopyrite to awaruite, native copper etc.

Freund et al. (1980) reported a large amount of carbon in solid-solution in forsterite. If it is the case, the agent for reduction may be carbon. Thus, we tried to analyse the carbon content of these rocks. We could not find, however, any carbon in this case by the technique employed in our laboratory, which can detect $0.005 \%$ carbon in rocks.

Grudin and Sekerin (1979) discussed the possibility of formation of native iron in brucite-bearing serpentinite. We also consider the role of serpentinization, especially for the shearing under the abundant presence of water. Shearing movement of silicate rocks may produce free radicals on their fractured surface, which reduce water. In this case, if $\mathrm{f}_{\mathrm{O}_{2}}$ is controlled by the equation, $\mathrm{H}_{2} \mathrm{O}=\mathrm{H}_{2}+1 / 2 \mathrm{O}_{2}, \quad \mathrm{f}_{\mathrm{O}_{3}}$ required to magnetite to iron (at $700 \mathrm{~K},<1.0 \times 10^{-33}$; at $800 \mathrm{~K},<1.4 \times 10^{-28}$ ) would be obtained, when $\mathrm{P}_{\mathrm{H}_{2}} / \mathrm{P}_{\mathrm{B}_{2} \mathrm{O}}$ is 1 to 10 , according to our calculation. The measurement of soil air on the active fault by Wakita et al. (1980) shows high content of hydrogen gas (more than $3 \%$ ). They did not measure the content of $\mathrm{H}_{2} \mathrm{O}$, however, if there is saturated water vapor at atmospheric pressure and $25^{\circ} \mathrm{C}, 3 \% \quad \mathrm{H}_{2}$ means $\mathrm{P}_{\mathrm{H}_{2}} / \mathrm{P}_{\mathrm{H}_{2} \mathrm{O}}=1.0$. The data may show us the possibility of producing of higher $P_{B_{2}} / P_{B, 0}$ in the occasion of serpentinization.

However, native iron has been found only in the second stage serpentine veins, and it is difficult to find the reason why such a reduction occurs only in those veins. Therefore, the mechanism of reduction and formation of native metals in serpentinites is still problematical.

Acknowledgements: We would like to appreciate very much M. Okamoto and Y. Inoue for their cooperative work at the beginning of this study. Prof. K. Momose and Prof. S. Matsuo have also concerned about our work. A part of expense of this study is defrayed by the Grant of special subject of the Ministry of Education, Science and Culture of Japan.

\section{References}

Borisenko, L.F,, Begizov, V.D. and Kurilenko, N. M. (1982), Native iron in ore-olivinites of Kachkanarskii massif. Doklady $A N$ SSSR, 264, 947-950.**

Challis, G.A. and Long, J.V.P. (1964), Wairauitea new cobalt-iron mineral. Mineral. Mag., 33, 942-948.

Chamberlain, J.A., McLeod, C.R., Traill, R.J. and Lachance, G.R. (1965), Native metals in the Muskox intrusion. Can. J. Earth Sci., 2, 188215.

Clark, A.H. (1969), Preliminary observation on chromian mackinawite and associated nativeiron, Mina do Abessedo, Vinhais, Portugal. N. Jb. Miner. Mh., 282-288.

Fabries, J. (1979), Spinel-olivine geothermometer in peridotites from ultramafic complexes. Contrib. Mineral. Petrol., 69, 329-336.

Freund, F., Kathrein, H., Wengeler, H. and Knobel, R. (1980), Carbon in solid solution in forsterite $-\mathrm{a}$ key to the untractable nature of reduced carbon in terrestrial and cosmogenic rocks. Geochim. Cosmochim. Acta, 44, 13191333.

Grudinin, M.I. and Sekerin, A.P. (1979), Native iron in ultrabasites of Shamanskii massif. Doklady $A N$ SSSR, 245 1208-1210**

Iizumi, S. (1968), The Ogawara ultrabasic intrusion, 
Nagano Prefecture in central Japan (Part 1). Earth Sci. no. 99, 267-277.

Kanehira, K., Banno, S. and Hashimoto, M. (1963), Notes on rock-forming minerals (28) Finding of awaruite (native nickel iron) from serpentinite near the City of Koti, Sikoku. J. Geol. Soc. Japan, 70, 272-277.

Kanehira, K., Banno, S. and Yui, S. (1975), Awaruite, heazlewoodite, and native copper in serpentinized peridotite from the Mineoka district, southern Boso peninsula. J. Japan. Assoc. Min. Petr. Econ. Geol., 70, 388-394.

Makimoto, H. (1978), Petrology of the Irisawai ultramafic complex in the Oshika district, Nagano Prefecture, central Japan-Petrography and chemical character of the Shiokawa peridotite mass - J. Geol. Soc. Japan, 84, 317329.

Misra, K.C. and Fleet, M.E. (1973), The chemical compositions of synthetic and natural pentlandite assemblages. Econ. Geol, 68, 518539.

Ramdohr, P. (1967), A widespread mineral association, connected with serpentinization. $N . J b$. Miner. Abh., 107, 241-265.

Research Group of Peridotite Intrusion (1967), Ultramafic rocks in Japan. $J$. Geol. Soc. Japan, 73, 543-553.

Okamoto, M., Inoue, Y. and Kuroda, Y. (1981),
Finding of native iron from the peridotites near Ogawara, Nagano Prefecture, Japan. J. Geol. Soc. Japan, 87, 597-599*.

Okamoto, M. (1981), Native metals from serpentinites. M. Sc. thesis, Shinshu Univ., 1$113^{*}$.

Onuki, H., Yoshida, T and Nedachi, M. (1981), Notes on petrography and rock-forming mineralogy(10) Awaruite and other accessory minerals coexisting with Tì-rich hydroandrodite in metamorphosed ultramafics of the Sanbagawa belt. J. Japan. Assoc. Min. Petr. Econ. Geol., 76, 372-375.

Skripnichenko, V.A., Cherepanov, A.A., Grib, V.P. and Pashkevich, S.M. (1982), Moissanite and native iron in serpentinites of Vetrenii belt. Doklady AN SSSR, 267, 1453-1455**.

Wakita, H., Nakamura, Y., Kita, I., Fujii, N. and Notsu, K. (1980), Hydrogen release: new indicator of fault activity. Science, 210, 188190.

Zimin, S.S., Granovskii, A.G., Latkin, A.S., Gorelov, V.N., Gorelova, N.M., Gulyaeva, T. Ya. and Chubarov, V.M. (1982), Minerals of platinoides, cobalt and nickel in one of the ultrabasic massifs. Doklady $A N$ SSSR, 264, 451-453**.

*: in Japanese

**: in Russian

\title{
中部日本，大河原付近の三波川带の超苦鉄孟岩体中の金属鉄とその随伴鉱物
}

\author{
酒井隆太郎·黑田 吉益 \\ 標記超塩基性岩体のダンかんらん岩には 3 つの時期の蛇紋石化作用があり，その第 2 期の蛇紋石脈中に金属鉄

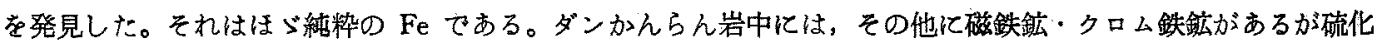 \\ 鉱物は存在しない。同じ岩体のウェールライト中からは金属鉄はほとんど発見されず，コバルト鉄が発見され \\ た。それは $\mathrm{CoFe}_{2}$ と表わされるもので，wairauite $(\mathrm{CoFe})$ とは異なる。なおっウェールライトからは awaruite， \\ 自然銅も発見され，その他にペントランド鉱，磁硫鉄鉱も存在する。また，ilvaite，andradite も見出される。 \\ てれらの鉱物の産状と化学組成について記載した。
}

